Besides the development of language to convey another culture, standardization is taking place due to the reduction of language to writing, and the increase in communication between districts. Differences in dialect tend to disappear. Pondo children use isiXosa school books and learn the Xosa words for things for which the word in the Pondo dialect is different:

e.g. Word.
milk
yesterday
lion
to hurry
grandfather

Xosa.
ubisi
pezolo
ingonyama
ukubaleka
ubawomkulu

Pondo.

intusi.

izolo.

ibubesi.

ukugijima.

umakulu.

There are now many Fingo immigrants in Pondoland and they are having considerable influence on accent and vocabulary.

Some words are falling out of use. Words for old leather garments that have not changed in meaning, and been applied to garments of European manufacture, are disappearing, and town-bred men often do not know the fifty-odd words describing the marking of cattle.

With contact, therefore, there is development of language, and at the same time standardization and atrophy. (Communicated by Monica HuNTER.)

\title{
The washing of the rojal stool at Ho (Togoland)
}

In May 1930 a new paramount chief ( fiaga ' King') was installed in Ho-Dome, after a long-continued quarrel about the ownership of the royal stool. At the ceremony of stool-washing representatives of the following towns were present: Akoefe, Sokode, Lume, Matse, Anfoeta, Atikpui, Klefe, Hodzokofe, Dzodze-Akoviefe, apart from the paramount chief himself (who bears the title of Howusu) and his sub-chiefs of Axõe and Ahliha.

Since the 'stool-father' (the hereditary owner of the stool, who is not the king himself) Kpondo had stubbornly refused to surrender the royal stool, the elected king and his private councillors M. D. Kosi and A. Fia Yawo were obliged to make a new stool. The washing of this stool was the last and most important act of the coronation.

This was done on May 4th, 1931. The day for the ceremony must be a Monday following a market day which is a Sunday. About seven o'clock in the morning a number of priests and priestesses made their appearance. Two of them, Afadi, who is the priest of the stool, and Kayi, had to do the washing. They entered the house in which the stool was kept, holding in their hands a bowl which contained a mixture of water and gin into which some flour was strewn, and prayed: 'Honoured grandfather, we carry you to the river this morning to wash you according to the custom of our forefathers. Help us so that everything may succeed well, and bless us.' 
Some of the sacrificial beverage was then drunk by the priests and the remainder was poured on the ground for the spirits of the fathers. The stool was enveloped in a sheep-skin and handed over to a young man of the Wusu (i.e. the royal) family, who had to carry it in the way a baby is carried and so that nobody could see it.

Every one there went in a long procession through Banyakoe down to the river Alale. But only the Hownsu and a few of the chiefs were allowed to approach the river itself. It was forbidden for any one to come into contact with the river before the washing had been done, for on this day the river was sacred. Cloths were stretched out to form a screen, and behind this the stool was examined by the priests. One of these now opened an egg at its point and placed it on a sandhill which he had made for this purpose. He scattered flour over the hill and put some cowrie shells beside it. Then Afadi offered a prayer in which he alluded to the quarrel about the stool and asked the river to allow them to wash the stool in its water. The river was on that day considered as a human being, of whom his guests request permission to do something in his house. The egg, flour, and cowrie shells were presents for him. After Afadi a priestess prayed in the same way. The priests now went back behind the stretched cloths, which were held by members of the Wusu family, and behind the screen an elder named Akpo performed the washing, after having said in a prayer-like speech that he did not do this by his own power but by that of his forbears, and that he prayed Alale to help him. Then he washed the stool, rubbing it with grass and a sponge, but without soap. The stool was then dried and smeared with white clay.

After this the Howusu had to go behind the screen. The priest had in his hand a bowl containing a mixture of water, palm wine, and white clay, he said: "The old people say, three is life. May this drink give you long life and successful government.' He tendered the potion nine times to the king, who drank from it three times. The Hownsu's forehead, cheeks, chest, and right arm were now rubbed with white clay (which is a symbol of righteousness or innocence), and he sat down again. The stool was enveloped in a white cloth; a priestess dipped water in a bowl, and after mixing it with a little gin and putting some leaves into it, sprinkled it over the people. The stool-priest Afadi went round and rubbed white clay on the foreheads, cheek, and chest of the people. The stool was wrapped in its sheepskin and handed over to its carrier, whereupon the stool-washer Akpo and after him the second priest Kayi pointed with the royal sword to the stool begging it to demonstrate that it was possessed with the spirits of the forefathers, by shaking as if in convulsions.

The whole crowd, including those who had not been allowed to attend the ceremony, now went back to the royal town of Dome, drumming, shouting, and singing. The Howusu and the chief of Sokode mounted their hammocks. ${ }^{1}$

1 Only these two persons enjoy the privilege of being carried in a hammock. 
When the procession arrived at Banyakoe, everybody noted that the stoolcarrier was seized by a spirit, he began to shiver and ran frantically amid the crowd; this was a welcome sight, the spirits of the forefathers had entered the stool.

The train then moved through Ahliha, where the Howusu swore to the local chief 'by the evening of the Ho people'I that he would always help him. The local chief replied in the same manner. The same ceremony took place in Ax̃̃e and in the Hausa town. In Heve, where the people were not quite willing to acknowledge the new Howusu, the latter addressed the leading people and said: 'We have now carried out our customs; if you want to go your own way and something evil happens to you, it is your own fault. If you follow me, I shall protect you.'

The people then went home. But the Howusu, the stool-catrier, and some other attendants called upon the important families 'to thank them', and were given a penny or something to drink. When the stool was finally brought into its house, Afadi prayed: ' Grandfather, I now bring you to your old place. We thank you for your help so that everything has gone well.' A sheep, which was owned by the stool, was slaughtered and its blood smeared on the stool. The meat was cooked, distributed among those present and eaten; but the Howusu left his share lying on the stool for more than an hour before he started eating it, the meaning being that he partook of the meat which had been offered to the forefathers, and was thus united with them. If after this ceremony he should ever have wicked thoughts in his head or bewitch a person, he would die. The same is true of his wives. They must have kind thoughts to every one.

On the afternoon of the following day the chiefs gathered again. The new stool-father M. D. Kosi gave a sheep and gin. A priest of the earth who held in his hand a bowl containing water mixed with flour stepped forward, turned eastward, and called in a loud voice: 'Eeh, eeh, listen, all ye spirits of the forefathers. The quarrel about the stool is ended, we have a new Howusu, and we have also a new stool. We rejoice that our Howusu is also a Paramount Chief. We know that you have helped us in this matter and we thank you for it. Here I bring you flour-water, not in my own power, but in the power of the grandfathers and grandmothers.' He then drank of it and poured the rest on the ground. The same he did with gin, saying: ' Give us better times, give long life and happy government to the Howusu and his chiefs.'

The sheep was then killed, after it had been swung in the air nine times. The blood was left to pour on to the ground, and the staff of the linguist as well as the royal swords of the chiefs were dipped into it. The chiefs took off their sandals and dipped their toes into the blood; the oldest among them, Gadzezu of Akoefe, came first, saying: 'If I break the bond with our Para-

$I$ 'The evening of the Ho people' is the evening on which the Ashanti invaded Ho and destroyed the town (1869). 
mount Chief, I have broken the oath.' I 'The Howusu himself was the last to swear, and he did it in these words : ' I am now your head; if I act evil against you I shall die; if any one acts evil against me, he will die.'

All the chiefs then drank wine out of a glass and Gadzezu said: "We have finished carrying out our customs. Drinking out of this glass means unity and progress; therefore ye all drink it for the well-being of our country. After these words he handed the glass to Ajku Ampim II, chief of Sokode, who is the first in everything, and who said: 'Howusu, you are now our Paramount Chief, therefore you are to keep us informed about everything, and we shall do the same with you. If we want to do you harm, we must die, and the same in your case.' When he had said this he drank, while Gadzezu held the glass. Gadzezu and the Howusu were the last to drink, the chief of Sokode holding the glass for Gadzezu, and the latter for the Howusu.

This was the end of the ceremony. The stool-father M. D. Kosi presented the two stool-priests with a sheep, two bottles of gin, two pots of palm wine, and a guinea.

(Communicated by Missionar PAUL WIEGRÄBE.)

\section{The Ethnology of African Sound-Instruments.}

I have read with great interest the recent essay ${ }^{2}$ by Erich von Hornbostel upon 'The Ethnology of African Sound-Instruments'. Its fullness and thoroughness and, for the most part, accuracy, make it a very valuable guide for ethnologists.

There are, however, several categorical statements in it which, in my opinion, require revision. One of these involves an error so serious that I feel constrained to draw the attention of your readers to it immediately, in order that they may not be misled into arriving at false conclusions which they may easily base upon it.

The error in question occurs in the section dealing with the so-called sansa (p. 297), where Hornbostel states: 'Africa has, however, produced a number of forms so characteristic that their occurrence outside that continent could not possibly have escaped notice. They present difficult problems to ethnologists, the most difficult of all being that of the sansa. Nowhere, even in Europe (with the exception of the musical box), do we find anything similar, on which the fancy of the evolutionist could build a theory...' And again: 'A weighty argument for the recent date of the instrument is the fact that it is nowhere mentioned in literature before the nineteenth century (Sachs) '. The second of these statements, backed as it is by the powerful authority of Curt Sachs, would appear to be final; nevertheless in my opinion it is wrong.

The sansa (to use the commonly accepted name of the instrument) was known to European travellers long before the nineteenth century. It was

$I$ i.e. the oath of 'the evening of the Ho people'.

2 Africa, vi. nos. 2 and 3. 